\title{
Adalet psikolojisi bakımından heyecanlar ve ihtiraslar
}

\author{
Yazan: Doçent Dr. Faruk Erem
}

\section{Plân : Gilìis}

BİRINCI BÖLÜM: Heyecanlar 1. heyecann tarifi, izahı 2. heyecanın diğer ruh hallerinden farkı (a. heyecanın ihsastan ayrılışı $b$. heyecanın ihtirasdan ayrilısı) 3 . heyecan ve irade 4. heyecanm çeşitleri $(\$ 1$. Hiddet: A. Cezayı azaltıcı sebep olarak hiddet «tahrik».B. Tahrikin șartları a. haksız ve tahrik edici fiil b. gazap c. şiddetli elem ç. tahrik neticesinde işlenen suç d. tepki müddeti e. tahrik ile taammüd arasında psikolojik mukayese $f$. tahrik ve meşru müdạfaa $g$. tahrik ve kasdı aşan suçlar h. tahrik ve tam olmayan akıl maluliyeti i. tahrik ve iştirak j. hususî tahrik halleri $k_{\text {j }}$ tahrikin çeşitleri $\$ 2$. Hayret $\$ 3$. Korku ( a. fobiler b. normal korkular) $\$ 4$. Yeis.

IKINCi BÖLÜM : Ihtiraslar $\$ 1$ sevgi ihtirası $\$ 3$ nefret ve intikam ihtirası.

GIRIŞ : [1] Normal insan kavraminın hakikate uygunluk değeri sadece nazaridir. Bir çokları müteselsil veya muayyen veya muayyen olmayan aralıklarla husule gelen ruhî fonksyonlar içinde

[1] BtBL.lYOGRAFYA : Altavilla, Psicologia giudiziaria, Torino 1925; Bruno, codice penale; Donnedieu de vabres, Droit criminel; Dwelshauvers (G.). Psiko. loji, Tunç. (Mustafa Şekip), lıstanbuł 19:8; Erem, Akıl maluliyeti, Adalet dergisi, 1946; Florian. Parte generale del diritto penale, C. 7 , bası 8, 1926; Garafalo, Criminologie: Garraud, Droit pénal trançajs; Gorce (M. M), Traite de philosohpie. Paris 1938; Logoz, Commentaire du code pénal suisse, Nöşatel, 193is: Longo, Commento del codice penale; Manzini. Trattato diritto penale italiano C. 2, bası 2. Torini 1926; Ribot, Hissiyat ruhiyatı, çev. Tunç (Mustafa Şekip), Istanbul 1927; Ongun (Cemil Sena Ongun), psikoloji dersleri, Istanbul 1985; Oner (Hamdi), Ceza hukukunda ehliyet ve mesuliyet, Ankara 1944; Pozzolini, Istituzioni di diritto penale. 1921; Sarp (Hatemi Senib), psikoloji, Istathal 1986; Westermarck (E.), l'origine et le développement des idées morales, Partis 1928 C. 1, 3. 
insan psikolojisinin tek esası «değişme»dir. Bu sebeple birbirinden ayrı ve ekseriya zit ruh durumunda bulunan insanın knormal veya *anormal sayılması için gereken "değişmez unsur * yani tasnif imkânı mevcụt değildir. Bu sebeple * normal insan * kavramı sadece fikrî bir mahsuldür. Griesinger'in dediŏi gíbi «şu adam delidir veya deg̛̣ldir? sözü ekseri hadiselerde hiç bir mana ifade etmez [1].

Heyecanlar ve ihtiraslar hakkındaki araştırma ve incelemeler aymı şahsın bütün hayatı boyunca snormal saylmasına imkân olmadığını göstermiştir.

Ĕger snormal»li̧̧in ölçüsü alınan ihsasın doğru ve e normal , li̧̧̛in ülçüsü de yanlış cidraks ise yani hakikatta var olan ile muhayyeleden gelen unsurların kariştırılmaması veya muhayyel olanı hakikî imiş gibi idrak etmemek ınormal ‘ lił̧i ve bunun aksi eanormal"liği teşkil ediyorsa umumiyetle her insanda bulunabilen heyecánlar ve ihtiraslar «normal * bir durumun varlığına imkân bırakmazlar.

O haldè Adalet psikolojisinde úmumî neticeler çıkarmaktan ziyade muayyen ruh durumu içinde bulunan insanın psikolojik hususiyetlerini tayine ve tanımăga çalışmak daha doğrudur.

\section{BİRINCí BölüM}

\section{HEYECANLAR}

1. Heyecanın tarifi ve izahı: Heyecan normal seyrinde akıp giden teessür hayatı içinde bariz bir sarsıntı halinde ve bazı fizyolojik gösterilerle birlikte husule gelen geçici psikolojik bir olaydır [2]. Korku. Hiddet [3], neşe keder, endişe, hayret, hicap, hayal sukutu, estetik heyecanlar gibi [4].

Heyecan muhtelif unsurlaan müdahalesi jle meydana gelen ve (son derecede kompleks bir şuur halidir) [5]. Her heyecan

[1] Altavilla'dan naklen s. 52

[2] Heyecanların mubtelif müellifler tarafindan yapilan tariflerinde ayrılık görülmemektedir. Dwelshauvers (s. 47) «akan teessür tonüsü içinde açı̣ła belli clan bir müddet hisleri alt üst eden ve kolayca seçilebilir uzvi de rişmelerle birlikte -gelen teessūr halleri* ne heyecan demekte; Gorce (s. 13̋8) heyecanı "şiddetli, fakat geçici bir teessïr hali olarak kabul etmekte; Sarp (s. 236) heyecanın «bir korku yahut hiddet aksesi, bir chagrin yahut desespoir buhranı gibi şiddetli takat geçici bir teessür hali» oldugunu bildirmekte; Ongun (s. 114) ise bunun 
aynı vasifta değildir. Korku hiddet ile, hàyret endişe ile, estetik heyecanlaa diøerleri ile aynı evsafta sayllamazlar. Heyecanlar arasında şiddet ve devam farkı da hadiseyi daha çeşitli kılar.

Heyecan darbesine maruz kalan ruh bir cismin kendinden daha sert bir cisme çarpmasında görülen hadiseye benzer bir deð̧işikliğe ư̆grar, diğerine çarpan cisimlerde görülen moleküllerin çöküntüsü, sıkışması gibi bir iç değişme husule gelir. Bu psikolojik hadise ile birlikte bir fizik hadisede kendini gösterir. Heyecanların doğurduğu bu fizik hadiseye Fiziyolojik tınlama (risonanza fisiologica) denir : Kalp atışında artış, vucut ısısında değişiklik, dimăg kan damarlarında kan miktarının çoğalışı, teneffüs hareketinin artışı veya azahışı vazomotör deđ̧işiklikler ve yüzde sararma, kızarmá. adele sıkışması, gevşemesi, çehrede heyecanın karakteristik mimikleri, iç ifrazlarda değgismeler ve saire gibi.

Fiziyolojik tınlama, yargıca sorguya çektiğgi kimsenin hakikî iç durumunu gösterebilecyk bir olay olması bakımından usul psikolojisinde ehemmiyet arzeder. Psikolojik hadise ile birlikte husule gelmiş olan fizyolojik tınlamà şahsı dợru bir müşahadede bulunmaktan ve hatırlama imkânundan az veya çok mahrum eder ki bu da şahadet psikolojisi bakımından ehemmiyetlidir.

Ihsaslarm doğru alınabilmesi ruhi bir muvazeneye (equilibrio psicologico) ihtiyaç gösterir. Ancak bu muvazene mevcut ise ihsas ahıcı organlarda doğru kaydetme ve şuurda tam bir alıcı kabiliyet kendini gösterir. Eğer bu muvazene bozulmuş ve bu suretle bazı imajlar ve ihsaslar ruhi durumda üstün bir tazyik icra etmis ise, bundan ihsas alıcı uzuvlarda adeta bir anestezi hasıl olur ve bunun neticesinde aralıkh, boşluklu! ihsaslar alınmağa başlar ve üstün tazyik eden unsurlarn tesiri ile diğer unsurlarm istikamet değiştirmesi, alınanın hufzedilmesi, kaydedilmesinde yanIışîklar, bozukluklar kendini gösterir.

Heyecanların hatırlama faaliyetine müessir olduğu aşikârdır. Heyecan halinde bulunan kimse ya, yeni ihsasları onları hifzetmek için yetecek şiddetle alamaz yahut heyecan hifzedilmiş olanlan

agelip geçici ve fakat birdenbire zuhur eden siddetli teessür bali- oldugunu yazmaktadır.

[i] Dwelshauvers s. 147; Gorce s. 138; Sarp s. 230

[4] Gorce s. 138

[5] Sarp s. 235 
siler veyahut hatırlamayı çok güçleştirir. Heyecanin hıfız ve hatırlama melekeleri üzerindeki tesirinin daha ileri gittiği, geçici amneziler bile doguracał̧ı ileri sürülmüștür [1].

lyi hıfzedilmiş ihsasların sırf hatırlama anında heyecan sebebi ile hatırlanamamaları da mümkündür. Sanıkların, suçtan zarar gören kimselerin, șahitlerin ifadelerindeki tezad ve karışıklık ifade verirken herhangi bir sebeple heyecan içinde bulunmalarından ileri gelebilir. Sadece bir kalabalık önünde konuşmak. heyecana dưşmek için kâfidir. Bu tesiri takdir etmeyen bir yargıcın israr etmesi, karşısındakini tehdit etmesi, korkutması heyecanı daha fazla arttırır.

Heyecan hakkinda muhtelif izah tarzlarına rastlanmaktadır: Heyecan ile iç güdü arasındaki bir çok hadiselerde görülen yakınlık, heyecanı iç güdü ile izah etmek fikrini doğurmuştur. Bu meyanda korkunun kendini koruma, cinsi heyecanın çoğalma iç $\breve{g u ̈ d u ̈ s u ̈ n d e n ~ g e l d i \not ̆ i ~ i l e r i ~ s u ̈ r u ̈ l m u ̈ s ̧ t u ̈ r ~[2] . ~}$

Heyecan hakkında en çok alâka uyandıran izah şekli W. James ve Lange [3] tarafindan ortaya atılan nazariyedir. Bu nazariye heyecanın fizyolojik esaslara göre izahını yapmaktadır. Nazariyenin esası her heyecanın fizyolojik bazı hareketlerden husule geldiłgidir. $O$ halde varlan nefice umumiyetle zannedilenin aksidir, yani heyecanlar, fizyolojik neticeleri değil, fizyolojik sebepler heyecan neticesini dơ̧urmaktadır. Meselâ vahşi bir hayvanın görülmesinden doğan korkuyu ele alalım. Bu vahşi hayvan *görüyorum, korkuyorum, titriyorum» demek yanlıştır $\mathrm{Bu}$ vahşi hayvanı "görüyorum, titriyorum" ve fiziyolijik bir hadise olan bu titreme neticesinde "bir vak'yı idrak ediyorum : Korku' [4].

Bu nazariye bu gün çürütülmüş sayılamaz. Lehde ve aleyhde olanlar arasında tartışmalar sürüp gitmektedir. Nazariyenin en kuvvetli tenkidini Sherrington yaptı [5]. Meseleyi hal için hayvan psikolojisini ele alan Sherrington dimağ ile vücut arasındaki sinirleri kesmiş ve buna rałmen hayvanda heyecan duygusunun ve harici gösterilerinin baki kaldığını görmüștür. O halde bu tec-

[1] Aitavilla, s. 57

[2] Bu mesele hakkında bk. Ongun s. 114

[3] Prof. Dr. Lange Kopenhak da ve piskolok William James Amerikada birbirlerinden ayrı olarak bu nazariyeyi ortaya atmışlardı. James tezini 1884 de, Lange 1880 ileri sürmüştür. Bu húsusta Dwelshauvers s. 157, Ribot s. 83

[4] James - Lange nazariyesinin izahı hakkında Gorce s. 140

[5] Sherrington'un araştırmaları hakkında Dwelshauvers s. 161 
rübe James-Lange nazariyesine aykırı düşmektedir. Çünkü sinirler kesildił̧i için titreme olayından korku olayına geçmeł̆e imkân olmadığı halde hayvanın korku veya hiddet alameti göstermesi James - Lange nazariyesine uymamaktadir.

Sherrington'nun fikrinin yerinde olup olmadığı kat'i surette halledilmiş sayllamaz. Çünkü yaptığı tecrübede dima g - beden rabıtasın tamamiyle kesmeğe muvaffak olup oimadığı henüz ispat edilememişstir.

Heyecanın James-Lange nazariyesinin hilafına olarak psikolojik izahı da yapılmıştır. Bu izah şekline göre heyecan hadisesinde birbirini takip eden zincir halkalan şöylece sıralanmıştır : Heyecan mevzuunun idraki, heyecan, heyecanın fizyolojik işaretleri.

Her iki nazariyede de hakikat hissesi vardır. Heyecanın fizyolojik izahı sademe - heyecanlara, psikolojik izahda his - heyecanlara daha ziyade uymaktadır. Bir sademe - heyecan olan ani korkuda fizyolojik reaksyon korku heyecanına takaddüm eder, bir his heyecanı olan yeis halinde fizyolojik neticeler en sonunda kendini gösterir.

2. Heyecanın diğẹ ruh hallerinden farkı: Heyecann diğer bazı ruh hallerinden ayırt edilmesi lâzımdır.

a) Heyecan ihsastan ayrı bir hadisedir. Ihsas bir asabın duygu kapmasından doğar, halbuki heyecanın kökü hariçte değil idraktedir. Heyecan fikirden doğar. (Şüphesiz heyecanı yapan fikir, duygu alan yollar vasıtası ile bize gelmiştir. Fakat burada duygu alan organlar ancak nakle yararlar. Hattâ bazan duyulan bir eksitasyon olmadı̆g halde, bir fikir kendine ait heyecana fursat verebilir. İhsaslar - bir manada - husule getirdikleri duygu organunda lokalize edildikleri halde, heyecanlar lokalize edilemezler. Ne korku ne hiddet için vucudumuzun bir noktasinda yer gösterilemez) [1].

b) Heyecan ihtirastan ayrılır. Heyecan ruh akışında geçici bir hadisedir. Ihtiras ise hislere hakim olan, ruh muvazenesini kendisine doğru çökerten ve geçici olmayan bir hadisedir. Psikolojideki ihtiras mefhumu ile Kriminoloji ve ceza hukukunda yer alan ihtiras suçlulư̆u mefhumu aym şeydir. thtiras suçluları ha-

[1] Sarp s. 285 
kikî ve asıl suçlu tipine dahil olmazlar, bunlar daha ziyade tesadüfî suçlular gurubundan ayrılmış bir kısındır [1].

Ihtiras ile heyecanın ayırt edilmesi psikolojide oldukça güç bir meseledir. Umumî menbaı bakımından ihtiras heyecandan dogar, bu bakımdan aralarında öz farkı gözükemez. Şiddet ölçüsü de her zaman doğru netice vermemektedir.

Ribot, ihtirası zihni hayattaki sabit fikir hadisèsine benzer bir hadise olarak kabul eder [2].

Altavilla, [3] his-heyecanlarm ihtiras oldưunu ve bu sebeple ihtirasın daimî veya müzmin bir heyecan sayılabileceğini söyler.

Kant'a göre [4] heyecan seddi şiddetle yıkıp yaylan sulara, ihtiras yatağını kazan ve değiştiren bir sele benzer. Heyecan bir sarhoşluk ihtiras bir hastalıktır.

3. Heyecan ve irade: Heyecanin șiddeti arttıkça irade kontrolüde o nisbette zayıflar [5]. Ruh akışındaki sükûtun ani bulanışı hareketlerde bir intizamsızlık dơ̆urur. Birbirini tutmayan adeli reaksiyonlar, kekelemeler, yersiz ve manasiz hareketlerde bulunmalar müşahede edilir. Heyecanın şiddeti ile irade kontrolunun zayiflaması yolundaki psikoloji bilgisi ceza hukukunda suçJunun mesuliyetini tayinde kanuni hükümler haline inkilap etmiştir. Isste psikolojik bir hadise olan heyecanın ceza hukukuna intikali irade kontrolü mefhumunun ceza mesuliyetinin-umumiyetle kabul edilen nazariyeye göre - ïzerine olan tesirini tetkik etmek zaruretinden doğmuştur.

Meselenin daha açık bir şekilde ele alınması için heyecanla-. rın çeşitlerini araştırmak gerektir. Heyecanın muhtelif tasnifleri yapılmıştır. Bu tasniflerden bazıları heyecanların mahiyetlerine göredir. Bazlları da daha ziyade heyecanın şiddetini ve neticesini göz önünde tutar. Irade kontrolü ile ilgili olan tasnifler bu sonunculardir.

Umumiyetle heyecanlar şiddet ve süreklilik bakımmdan ikiye ayrilurlar: daha ziyade ani sayılabilen sademe heyecanlar ve daha ziyade sürekli sayllabilen his - heyecanlar.

[1] Pozzolidi n. 140

[2] Ribot s, 27.

[3] Altavilla s. 53

[4] Altavilla'dan naklen s. 53

[5] Goree s. 189 
Sademe - Heyecan hislerin akışında ani bir karģaşalı doğurur ve fizyolojik sahada yine bariz ve sür'atli hadiselere müncer olur. His - heyecan ise bir sademe - heyecandan (meselâ hiç beklenilmeyen bir kara haberin alınması) ile başlar. Şiddeti zayıflar. ruhi bir çöküntü, bitginlik dơ̆urur, fizyolojik gösterileri de digerininkine benzemez.

Buna yakın bir tasnifde Wundt tarafindan yapılımıstır. (Wund vaktiyle kantın da fark ettiği iki nevi heyecanı ayırmıştır: 1 . Sthenique heyecanlar, 2. asthenique heyecanlar. Birincisi sürur ve hiddet gibi tenebbühe tekabül eden heyecanlar, ikincisi ise her nevi korkular gibi ani felci mucip olan yahut iztirap, keder gibi müterakki bir çöküntüyü (depression) mucip olan heyecanlardır) [1]. Astenik heyecanlarda dimažda anemi ve bunun neticesinde bitkinlik, yorgunluk hissi, çalş̧ma isteksizliği. bazan uy. kusuzluk husule gelir. Kuvvetli kederler normal tahriklere karş̧ bir hissizlik tevlit eder. Bu hissizliğin menbal astenik heyecanlaIm şıư iaaliyetine engel oluşundandır. Çok sevdiği bir kimsenin öiümü, bizzat kendisi yakın bir tehlikeye maruz bulunan bir şahsa bildirilecek olursa, bu ölüm hadisesi üzęrinde ruhi melekelerini toplayamaz. Karşı karşıya bulunduğu tehlike kendisini daka farla ilgilendirmektedir. Bu hali izah etmek gü̧ değildir: Idrak ve dikkat yeni ihsasların tevlit ettiợi alâka unsuru tarah̆ndan sevkedildiğine göre, şahısta husule gelmiș olan heyecan hali, dikkatini münhasiran muayyen bir fikir toplujugu üzerinde temerküz eitirir ve bu hal her türlï yabanc imajin husulïne engel olur.

Stenik heyecanlarda heyecani tevlit eden hadiseye yabanca unsurlar ekseriya idrak edilmez veya yanlıs anlaşhin, ikame hallerine rastlanır. Bir otobüs bir arabaya çarpmiak üzere iken 0 sirada caddede kavga eden bir kaç kişiden biri silâh ile ateş etmiş olsa, otobüste veya arabäda bulunanlardan hemen hiç kimse bu hadise hakkında malumal veremez yahut söyledikleri yanlıştır, meselâ oiobüste bulunan bir kimse aynı otobüste bulunan tanmadiğı ve sadece otobüste dikkat etmesizin görmüş oldư̆u bir kimsenin kavgada silâh çeken şahıs olduğuna şahadet edebilir.

$\mathrm{Bu}$ iki nevi heyecan arasında intikal hadisesi cereyan edebilir. Manzini'ye göre [2] stenik heyecan (galvan) ferdi reaksyon

[1] Ongur s. 120 n. 9

[2] Manzini n. 4岂要 
enerijsinin tükenmesi yahut yeni sebeplerin inzimamı ile astenik bir heyecana (çöküntü) inkilap edebileceğini ve astenik bir heyecanın da dahili ve spontane bir değişme yahut harici vesileler yüzünden stenik bir heyecana inkilap edebileceyini haklı olarak ileri sürmüş̧ür.

4. Heyecanların çeşitleri; Heyecanların çeşitleri pek çoktur. Belli başlı heyecanların tetkiki ve bunların kanun hükümlerine intikal şekli üzerinde durmakta faide vardır.

\section{§ 1, HIDDET}

Hiddet heyecanının ceza hukukundaki adı stahrik" dir. Ceza hukuku her türlũ hiddeti deð̛il, haksız bir tahrikden mütevellit olani nazara almaktadır.

A. Cezayı azaltıcı sebep: Ceza kanununun 51 inci maddesi tahrik halini yukarda görüldü̆̋̈ü veçhile cezayı, azaltıcı sebep olarak kabul etmiştir. Tahrik edilmiş olanın cezàsını indirmeğe ve bunu cezanın kanuni azaltıcl sebebi yapmağa kanun kurucuyu sevkeden düşünce nedir? Bu hususta biri psikolojik dið̧eri hukuki iki fikir ileri sürebilir:

a. Hiddet iradeye şıddetle ve süratle tesir eder. Hareketlerin şuurlu bir kontrolü insanın mücehhez olduğu akıl ile sağlanabilir. Fakat aklın tesiri batidir, bu sebeble ani tesir eden her şey ve bu meyanda bir heyecandan ibaret olan hiddet, iyi düşünmek için gereken zaman vè sükûna imkân bırakmaz [1]. $O$ halde tahrik (fizio-psikolojik bir hadisenin; insan ruhunun şiddetli bir safhasına muayyen hukuki neticeler tahmil edilmek suretiyle hukukan tanınmasıdir [2] [3].

[1] Buna benzer bir izah sekli hakknda Pozzolini n. 140

[2] Manzini n. 433

[3] Garafalo hiddeti, sựlu psikolojisi bakımından ayrı bir tetkike tâbi tutmuştur. Garafaloya göre (s. 26), hiddet ruhi fonksyonlarm teşevvüşü, harici tahriklere karşı dimag reaksyonunun anormal bir durumdur ve ekseriya dimăg uzuvlarını iyi tekâmül etmemis olması yahut asap sisteminin irsi bir sebeb yüzünden aşırı bir zafiyete uğramış bulunması şeklindeki bir dejenere durumla mäterafiktir. Çok şiddetli bir hiddete kapulmış olan bir kimse, kendini kızdırına eli ile vurabilir, fakat ona pıçăğı batırnaz. Hiddet sadece karakteri mübalağa. landurı. Hiddet altrüvist duygudan gelen ahlak mukavemeti kuvvetine sahip olmıyan kimselerde suçun müessir sebèbidir. 
b. Ilk suçlu tahrik eden kimsedir. Onun bu suretle işlemiş olduğu hatanın suçlunun hatasından indirilmesi [1] ve bilnetice cezanın tenzili lâzımdır.

Hiddet neticesinde failin akli melekelerinde hasıl olan teșevvüş ve hata edenin yalnız kendisi olmadığı yolundaki iki fikrin telif edilmesi ve kanun koyucunun bu maksatla haksız tahriki cezayı azaltan bir sebeb olarak kabul ettił̧̧i mütlâası [2] makuldür ve hem hukukî ve hemde psikolojik bir izah şeklini ifade eder.

B. Tahrikin şartlari: 51 inci maddeye göre cezayı azaltıcı bir sebeb olan tahrikin kabulü için suçun haksız ve tahrik edici bir fiilden ileri gelen bir gazap yahut şiddetli bir elem tesiri alunda işlenilmiş olması lâzındır. O halde nelerin haksız bir tahrik saylabileceği ve 'gazap〉 şiddetli celem» terimlerinden ne kaste- . dileceğini araştırmak lâzımdır.

a) Haksız ve tahrik edici fiil: Ortada haksıı ve tahrik edici bir fiil mevcut değilse tahrikten bahsedilemez.:

aa. Tahrik edici fiil: Ceza kanunu nelerin tahrik edici fiil sayılacağını göstermemiştir. Maddi cebirden başka [3] tehdid, ağır sövme, ve 51 inci madde mucibince nazara alınabilecek neticeleri doğurabilen heyecanları tevlit eden diğer bütün filller (icabı veya selbi) buraya dahildir. Fakat her halde ortada müspet bir vakıanın bulunması lâzındır. Bu sebeble: (vehim ve zan tahriki müstelzim görülememektedir) [4].

Fiilin tahrik etme kudretini takdirde temamlyie nisbi kıstaslar kullanilacaktır [5]. Bunun için tahrik edilmiş olan kimsenin ve tahrik edenin şahsî vasıfları, ikisi arasındaki münasebet, mahal ve zaman şartları vesaire nazara alınacaktır.

Ancak bir insanın fiili tahrike sebeb olabilir. Insandan gayrısının her hangi bir hareketine karşı tahrik sebebi ileri sürüle*

[1] Donnedieu De Vabres n. 759

[2] Ayns müellif .n. 759

[3] 1. C. D. 1.9 .936 esas 2516 karar 1353 Tem. kar. 936 s. 219: (Mahkemenin kabulüne göre suçlunun başındnn taq ile yaralanmasının haksız tahrik mahiyetinde olmayı 59 uncu madde dairesinde takdiri tahtif selsebi olarak kabulü yolsuzdur.)

[4] Adalet Bakanlign, tamian 31.5.93̈ 1. 2090

[5] bk. 1. C. D. 14.10 .935 esas 1512 karar 1579 Tem, kar mec $\$ 196$ 
mez. Bu sebeble kendinin hrpaladı̆̆ı veya kızdirdığı bir hayvanin fiili neticesinde suç işleyen bir kimsenin tahrik edilmiş oldugunu iddia etmesine cevaz verilemez [1]. Hükmi şahıslara izafe edilen faaliyette bahis mevzuu deợildir, çünkü hükmi şahsın muameleleri tahrikde şart koşulan maddi fiillerden madut değildir.

Tahrik edilenin fiilin vukuu esnasında hazır bulunması veya bizzat fiil ile temas halinde olması şart değildir.

Bir veya bir kaç kişinin tek'fiilinden birden ziyade kimse tahrik edilmiş olabilir, birden ziyade fiilden bir tek kimsenin tahrik edilmiş olabilecę̧̣ gibi, Bu fiillerin aynı zamanda veya ayrı ayrı yapılmıs olmalarının ehemmiyeti yoktur.

bb. Fiilin haksızlığı: Tahrikin cezayı azaltıcı bir sebeb olarak kabulü için suçu işleyenin haksız olan bịr tahrike yani kendisi haksız sayılacak bir tahrike maruz kalmış olması lâzımdır [2]. Tahrikin haksızlı̆̆ın objektif olarak de ờil, failin makul düşüncesinde aramalıdır [3]. Bu sebeble: uzun zamandanberi imam nikâhı ile evli ve iki çocukları olduktan sonra suçlunun askere gitmesi esnasında bir başkası ile yaşamağa başlayan kadını suçlunun diğer bir erkekle yatakta görmesi halinde öldürmesi hadisenin haksizlığına mani olamıacağına) karar verilmiştir [4]. Haksızlığın tayininde şü ölçü kolaylıkla tatbik edilebilir: Tahrikin haksız olması demek, tahrikin meşru bir sebebe dayanmamasi demektlr [5].

Hakl bir fiil de tahrik edici olabilir. Fakat kanun cezayı azaltmak kudretini ancak haksız olan fiilden ileri gelen tahrike tanımıştır. Bu sebeble usulüne uygun bir şekilde ittihaz edilmiş bir disiplin tetbiri ona maruz kalan kimsede bir hiddet hali dogurabilirsede bu hal 51 inci maddeye giremez [6].

Haksızlı̆̆ın ölçüsünde taarruz edenle suçlu arasindaki münasebet daima göz önünde tutulmalıdır. Bu sebeble: (hayvanları tarlaya soktư̆gundan dolayı büyük babasının azarlamasından' in-

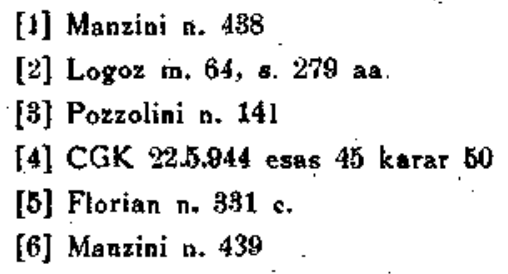


fial duyan suçlunun onu öldürmesi halinde 51 inci maddenin tatbik edilemiyeceğine) karar verilmiştir [1].

Haksızlı̆ın şahıslar arasındaki münasebete göre ölçülmesi lâzım geleceğinden bir başka netice daha ortaya çıkmaktadır. Daimî bir surette veya fiil esnasinda ehliyetsiz olanlarn hareketinin haksız tahrik teşkil etmemesi lâzım geldiği ve tahrik edenin şahsi durumu hakkındaki kusura dayanmyan hata halleri haricinde tahrikin kabul edilmemesi icap ettiği ileri sürülmüştür [2].

Tahrikin haksız olması lâżm geldiğinden gayrî iradi fiiller 51 inci maddedeki cezayı azaltma sebebine meydan veremezler, gayrı iradi olarak bir kimseye çarpmak gibi. Fakat taksirli bir fiilin tahrik edici sayılması isabetli olur.

Karşıltklı taarruz hallerinde haksızlığın tayini bazı güçlükler arzeder. Iki türlü karşılhklı taarruz tasavvur edilebilir:

1. Müteakip, mütekabil taarruz: Tahrik eden kimse, karşı tarafın tahrik edilmiş olan fiilinden müteessir olarak mukabelede bulunması şeklinde ortaya çıkan bu çeşit hadiselerde haksızlık ilk defa tahrik edenin fiilindedir. Aksinin kabulü mantıka uymaz [3] ve suçu için mazeret hazırlamak istiyentlere imkân verir. Fakat ilk defa tahrik edenin haksiz tahrik sebebinden istifade edemiyeceği kaidesi mutlak değildir. Tahrikden mütevellit fiil, makul nisbeti aşmı ş ise ilk tahrik eden de cezayı azaltıcı sebebden istifade etmelidir. [4].

2. Hemzaman mütekabil taarruz: Bu hale şüphesiz ender tesadüf edilir. Aynı anda iki haksız taarruzun meydana geldił̧i hâdiselerde kendini gösterir. Birbirine düşman olan iki kimse ani olarak karşılaşır ve eski düşmanliklarnnn tesiri ile biribirine hakarete başlarlar ve birden ve aynı zamanda biribirleri üzerine atılırlarsa bu vaziyete işledikleri suçlar için her ikisi hakkında tahrik sebebi kabul edilir [5].

cc. Tahrik fiilinin hedefi: Tahrik edici fiilin suçluya tevcih edilmiş olmassı şart de ğildir. Suçlunun eşine yahut onun kendisi-

[1] CGK 15.7.980 karar 189

[2] Manzini n. 439

[3] 2. C. D. 12.11.9j6 karar 12505. Köseoğla in. 31 : (Evvełâ suç̣tu tarafindan davaciya tecaviiz edildiği halde suçiu iehine 51 inci maddenin tatbiki yolsuzudur.)

[4] Bu hususta Manzini n. 439

[5] Manzini n. 459 
ne yakın bulunduğu ve sevdiği diğer herhangi bir kimseye karşı tevcih edilmiş olabileceği gibi [1] tehinde insanî hissiyatın uyandığı bir yabanci șahsa karşı da [2] tevcih edilmiş olabilir.

Mala müteveccih haksız bir taarruzdan mütevellit hiddet tesiri altında işlenmiş bulunan suçlarda 51 inci maddenin tatbiki lâzım gelip gelmeyeceł̧ üzerinde durulması gereken bir meseledir. Maddenin yazılışındaki umumî ifade tarzı bu nevi suçlarda da tahriki kabule müsaittir.

b) Gazap : Ortada sadece haksız ve tahrik edici bir fiilin bulunması kâfi değildir. Bu fillden dolayı şahsın gazaba gelmesi de lâzımdir. Gazap şiddetli bir hiddet manasına gelir.

aa. Psikolojik bakımdan hiddet : Hiddet mefhumu umumiyetle arızî bir enerji artışı ifade eder. Fizyolojik sahada kendine has bazı tepkiler uyandırır: Damarlarda şişme, sesde çatlaklık, vecudun atılmak ister gibi bir hareket.hazırlı̆ı durumuna geçişi. bazı guddelerde ifraz arttı mı, kadınlarda süt kesilmesi vesaire. Hiddet heyecanının az çok tekâmüle ư̆ramış bir his olduğu kabul edilmektedir. Tegaddi ve kendini koruma duygusuna dayanan iptidâî hiddet daha żyade fikrî bir mahiyete dơ̆ru tekâmül eder.

Münevver insan ile iptidaî durumunu muhafaza eden insan arasında hiddęti yenip yenememek bakımından fark vardır. Münevver insan için basit bir kızgınlı doğurabilecek bir vak'a jptídaî kalmış insan için gazap hali tevlit eder. Bu sebeple bazı suç hâdiselerinde gayet ufak sebeplerden ă̆ır suçlarm işlendiği görülmektedir.

Eski psikoloklar hiddete kkısa süren delilik derlerdi. Fakat hiddeti «akıl maluliyeti" gurubuna ithal edecek olan bu düşünce ceza hukukunda kabul edilemez. Fakat hiddetin bazı akıl maluliyeti hallerinde çok büyük bir şiddet arzettiği doğrudur [1].

bb. Ceza hukuku bakımından hiddet : Haksız tahrikte kanunun itibare aldığı hiddet <gazap kelimesinin ifadesine uygun bir şiddette olan hiddettir. $O$ halde şiddetli sayulamıyacak bir hiddet haksız tahrikin unsuru olamaz. Buna mukabil hiddet heyecanı basit tagayyürlerden daha fazlasına yani hakikî bir patolojik duruma sebep olursa artık tahrikten deyil \& tam veya tam olmayan akul maluliyetinden" bahsetmek lâzımdìr [3].

[1] Pozzolini n. $14:$

[2] Majno m. 51 n. 236

[3] Manzini n. 433 
Gâzap hali tahrikin bir şartı olduğuna göre 51 inci maddenin tatbikinde bu şartın mevcut olup olmadı̆̆ı̀nı araştirmak lâzımdır. Fakat mahkeme içtihadının tetkikinden bu şartlar aranmadığı neticesine varmak kabildir. (tatbikatta yargıৎ kanun kurucunun aradıği bu şartı aramamakta ve haksız tahriki mucip bir fiilin mevcut olduğunu kabul edince gazap veya şiddetli elem halinin mevcudiyetini farzetmektedir) [1], Yani hakssz veya tahrik edici fiil sabit olmuş ise ona maruz kalanin hiddete veya şiddetli eleme kapılacăğ neticesi istihraç edilmekte, fakat bu neticenin hakikaten husule gelip gelmedið̣̆i araștırılmamaktadır, $O$ halde 51 inci madde hükmüne psikolojik bir hal hakkında kanuni bir karine nazarı ile bakılabilir.

c) Şiddeti elem: Ceza Kanununu cezayı azaltan bu kanuni sebebin tatbikinde tahrikten ileri gelen iki psikolojik hali bir tutmaktadır. Bu iki halden biri evvelce tetkik eltiğimiz "gazap? ikincisi *șiddetli elem" dir.

Haksız bir tahrikden mütevellit şiddetli bir elem tesiri altımda suç işlemnek hali psikolojik bakımdan imkânsızdır. Bu sebeble kanunun hüknıü psikolojik hakikatlere pek uymamaktadır, şöyleki :

Psikolojide elem tabiri ile iki hal işaret ediltir. Bunlardan birincisi thaz mukabili olarak kullanlan elem, ikincisi de his-heyecanlardan olan ve keder yeis manalanna yaklaşan elem halidir. $\mathrm{Bu}$ her iki manada 51 inci maddedeki selemp e uymamaktadır. Çünkü elem hali dinamik neticeler dogururmała müsait bir hal değiidir. Sakin ve ruhi kuvvetlerde bir çöküntüyü, psikolojik bir iktidarsız]ı̆ı 1 ifade eder. Bu sebeble Carrara iztirabın lisanı sü* kûttur ' [2] demiş̧ti. Elem halinde bir kimsenin suç işlemesi imkânsızdır. Suç işlenirken bir enerji artışı, hakiki bir hiddetlenme mevcuttur. $O$ halde hiddet halinde sų̧ işlemek mümkünsede sakin bir durum ifade eden elem halinde suç işlèmek imkânsızdır.

Elem tabiri ile kanun bilnetice hiddete inkilap eden bir hali kasdetmek istemiştir. Meyhaz kanunun hazırlayıcı çalı̧̧malarından gazap ile șiddetli elem arasındaki farkın haksız tahrikten mütevellit reaksyonun doğrudan doğruya olup olmamasına istinat ettirildiŏi anlaşılmaktadır. Hiddet ekseriya suçlunun şahsına tevcih edilmiş bir taarruzdan doğar. Böyle birl halde şahısda en

[1] Pozzolini n. 14 ]

[2] Longo'dan naklen m. 51 n. 7 
kuvvetli iç güdüler harekete geçer ve bu neticenin doğması için bir iç çalışma neticesinde teksif edici bir faaliyete ihtiyaç yoktur. Elem ise ekseriya suçlunun sevdiø̆i kimselere veya şeylere karşı vukua gelen taarruzlardan dợar. Böyle hallerde tahrik doğuştan gelen duygulara değil, müktesep duygulara dayanı ve bu halde duyguyu stanik heyecana inkilap ettirmek için de dahilî bir ruhi faaliyete ihtiyaç varḍ̂r [1].

Elem ile gazap arasinda bu suretle bir dereceye kadar bir fark mevcut olabilirse de kanunumuzun böyle bir tasnife sadık kalışı onun bu bakımdan tatbik kabiliyetini azaltmaktadır. "şiddetli elem" in de netice itibariyle bir hiddete müncer olması lâzım geleceğine göre, kanunda yalnız haksız bir tahrikten mütevellit gazap tesiri ile suç işleme halinden bahsetmekle iktifa etmek yerinde olurdu [2].

Kanunda sşiddetli elem" tabiri kullanılmaktadır. Bundan mảksat hakiki bir heyecan halini işaret etmektir [3]. Her hangi bir elem duygusu 1şiddetli, mefhumuna girmez.

Elem yalnı manevi olabilir. Maddi elem (yüze vurulan darbe gibi) sadece tahrik edici fiili teşkil eder [4].

ç) Tahrik neticesinde işlenilen suç: Işlenilmiş olan şuç ne olursa olsun tahrik kabul edilebilirmi? Bazl yabancı kanunlar, ezcümle fransız ceza kanunu tahriki umumi bir kaide olarak de.ğil, ancak bazı suçlar için kabul etmiştir.

Bu mesele kanunun hazırlanışı sırasında bahis mevzuu olmuş ve tahrikin ceza kanununun umumi kısmindamı, yoksa eşhasa karşı işlenilen suçlara ait olmak üzere hususi kısmındamı yer alması lâzım geleceği hușusunda cereyan eden tartışma sonunda tahriki umumi hükümler arasına almak fikri galip gelmiștir [5]. Bu sebeble 51 inci madde umumi hükümlerden bahseden birinci kitapta yer almiş. bulunmaktadır.

[1] Bo izah sekli hakkında Manzini n. 434

[2] Pozzolini n. 141 : (Bu tefrika lüzum yoktur, çünkü hâkimier haksız tahrikin meveut oldugunu kabul edince gazsp ve elemin de meveudiyetini farzetmektedirler. O halde bu ikisi arasındaki farkı araştırmał̧a ihtiyą̧ yoktur. Sonra belki de bu tefrik yalnız nazarî psikolojide meveuttur.)

[3] Manzini n. 434

[4] Manzini n. 434

[5] İtalyan $Y_{8}$. kararı, Manzioi'den naklen n. 443 Il. 
O halde tahrik neticesinde işlenilmiş olan suç ne olursa olsun cezayı azalticı sebeb tatbik olunabilecektir. Bu sebeble yalnız şahıslara karşı olan cebir ve şiddet fiilleri için değií, şahsi hürriyete, mesken masuniyetine. umumî adaba karşı işlenmiş suçlarla kasden yangın çıkarma [1] tehdit [2] vesaire gibi suçlara da tatbik edilir. Mala karşı işlenmiş bir suç hakkında tahrikin kabulü lâzımdır [3]. Tahrik ve tehdid suçunun birlikte bulunduğu hallerde orlaya bazan tereddütlü bir durum çıabilir. Kaide tahrikin tehdit fiilinin cezasın azaltacağıdır. Fakat tehdit kasdının bulunmadığ' sabit olan hallerde faile ceza verilemez [4].

Tahrik hükmü bütün suçlara ve bu meyanda kabahatlerede tatbik olunur.

Hususi kanunlardaki suçlar hakkında Ceza Kanununun 10 uncu maddesi hükmü cari olacaktır.

Tahrikin tatbiki bakımından tam suç ile teşebbüs halinde kalmış suçlar arasında fark yoktur.

Emirlere ve nizamlara riayetsizlikten mütevelitit taksirli suçlarda da tahrik kabul edilebilir. Haksız bir tahrik neticesinde emir ve nizamlara riayet etme vazifesini yerine getiremeyen bir suçlunun tahrikten istifadesine kanuni mani yokttir [?].

Haksız tahrik neticesinde işlenilmiş olan suçun mağdurunun kim olacağı üzerinde durulması gereken meselelerdendir. 51 inci madde tahrik edilmiş suçun mağdurunun tahrik eden kimse olması lâzım geleceğini söylememektedir. Fakat fiilin tahrik edene karş̣ı işlenmesi lâzım geleceği aşikâr gibi gözükmektedir. Kasdi suçlarda fiilin üçüncü bir şahsa karş̣̂ işlenmesí, fiì hiddet esnasında işlenmiş olsa bile kabul edilemeyecek bir haldedir. Çünkü zayıf ve hadisede hiç bir kusuru olmayan bir kimse zararma kendi hiddetini teskin etmek hakkı suçluya verrilemez [6].

[1] İtalyan Yg. kararı, Bruno m. 51

[2] Italyan Yg. karar, Bruno m. 51

[3] Manzini n. 448 Il.

[4] Manzini n. 443 Il.

[5] Manzini bu hale su misali vermektedir (n. 443 II). Bir demir yolu bekçisine küfretmek ve taş atmak suretiyle birką̧ çocuk eğlenmektedir. Birgün bekçi kendisi ile eģlenen çocukları görür. Kizgıalik esnałında demiryolu geçidini kapamăğ uoutur, tren bir arabaya çarpar. Bekçi tahrik halinden istifade edecektir.

[6] Bu mesele hakkuda Manzini n. 443 III. 
Ĕger fiil üçüncü şahsa karșı kusursuz bir hata yahut dił̆er bir kaza neticesinde ișlenmiş ise, suç failinin 52 inci maddeye müsteniden cezayı azaltıcı tahrik sebebinden istifadesi mümkündür. Zaten 51 inci madde (bu hükmü yalnız kan suçlanna ait kısımda kabul eden meyhaz kanun projesinden farklı olarak) nin umumi kısma alınması sebeblerinden biri de hata neticesinde suçu tahrik eden den başka bir kimse aleyhine işleyen kimsenin durumunu bu maddeye ithali temindir [1].

Ĕger hata kusurlu ise tahrik hükmü tatbik edilemez, çünkü kendini kendi kusuru ile hiddete kaptırmak ne objektif nede sübjektif bakımından haksız tahrik saylamaz [2].

Tahrik edici fiil ile bunun neticesinde işlenmiş olan suç arasında bir münasebetin mevcudiyetini kanun sarahaten şart koşmamaktadır. Fakat bu şart tahrik mefhumunda bizatihi mevcuttur. Ancak haksız bir tahrik neticesinde işlenilen suça tahrik edilmiş suç denilebilir. $O$ halde tahrik eden fiil ile tahrik edilmiş suç arasında bir illiyet bağı mevcuttur. Bu illiyet bă̆ı nisbeti icap ettirir, çünkü bir sebeb ancak iktidarı nisbetinde nètice doğurabilir. Eğer suç tahrik eden fiilden daha ăgır ise suç sebebinin tahrik olduợu söylenemez. Böyle bir halde tahrik sebeb değil, bir vesiledir [3].

d) Tepki müddeti : Kanun haksız bir tahrikten mütevellit gazap veya şiddetli elemin stesiri altında suç işlemekten bahsetmektedir. $O$ halde suçun haksız tahrikin tesiri geçmeden evvel işlenmiş olması lâzımdır. Bu tesir ne zaman başlar, ne zaman sona erer ? yani tahrikte tepki müddeti nedir? Şahıstan șahısa değişen bir müddetin kronometre ile ölçülmesi imkânsızdır [4]. $\mathrm{O}$ halde psikolojik güçlükler göz önünde tutularak (bu halin sihhat ile ölçülmesine imkan olmadığı) [5] nı kabul etmelidir.

Diğer taraftan tahrik ediçi fiil ile suçun «filhal * veya buna yakın olması diger bir psikolojik bilgiye de aykırıdır. Modern psikoloji heyecan mevzuunda yalnız tahrik edici fiilin değil, vukubulmuş bir fiilin sadece haturlanmasının da bir galeyan hali tevlit edebjleceğini kabul etmektedir. Geçmiş bir mevzuun hatırlanması taar-

[1] Manzini n. 445 Ill.

[2] Mânzini n. 443 III.

[ث] Manzini n. 443 I.

[4] Bu hususta Pozzolini a. 141; Mainno m. 51 n. 237; Florian m. 331 c.

[5] Oner s. $90 \mathrm{IV}$

Hukuk Fakültesi Mecmuası 
ruzun vukua geldiği anda tevlit ettiğinden daha büyük bir hiddet dơ̆urabilir [1]. Ceza kanununun ihzarî çalışmalanndan şu anlaşılmaktadır. Gazap ve şiddetli elem arasında fark gözetmeye vaz'ı kanunu sevkeden sebeplerin biri de eski bir tahrikten mütevellit suçlarda tahriki kabul edip etmeme hususundaki tereddütleri izale etmek isteğidir [2].

İşe bu mütaleâlara müsteniden yargitay " 51 inci maddenin tatbiki için suçun haksız bir tahrikin husule getirdiği elemin tesiri altında ișlenmesi lâzım olup tesir ve elemi mucip olan haksız fiilin suç ile aynı zamanda ika edilmiş bulunmasının şart olmadı. ğına karar vermiş̧ir [3].

O halde şu neticeye varmak lâzımdır : Tahrik edici fiil ile suç arasında zaman geçmiş olması tahrik sebebinin kabulüne mani deł̧ildir. Fakat bu iki vak'a arasında bir zaman geçmiş olması suçun haksız tahrikten gayri bir sebepten neşet etmesi ihtimalini de ortaya atar. Hakim geçmiş zamanın uzunluğu ile hâdisenin diğer şartlarını da araştırarak zaman geçmiş olmasının hiddet veya elemi ortadan kaldınıp kaldırmadığını takdir eder [4]. Hakimin takdir hakkı mutlaktır. Fakat sadece zaman geçmiş olmasina dayanarak haksız tahrik hükmünü tatbikten çekinmesi halinde verdiği hüküm "gerekçesiz" sayılarak bozulur, çünkü hakim bu şekilde hareket etmekle kanuna, kanunda mevcut olmayan bir karine ithal etmiş olmaktadır [4].

e) Tahrik ile teammüt arasında psikolojik mukayese: Tahrikin psikolojik esası belirtildikten sonra ortaya bir mesele çımaktadır: Teammüt ile işlenen suçlarda tahrik kabul edilebilir mi? Tereddüt tahrik ve teammüdün psikolojik mahiyeti arasında bir tezat bulunduğu kanaatından ileri gelmektedir : Teammütte sürekli ve inatçı bir ruhî hakimiyet müssahade edilir, halbuki heyecan geçicidir ve daha ziyade bir coşkunluk hâdisesidir. $O$ halde teammüt ile adam öldürmenin cezasını tahrikten dolayı indirmeğe imkần yoktur.

Fakat bu düşüncedeki kat'iyet, heyecanlar hakkından evvelce verilen psikolojik bilgiye uymamaktadır. Her ne kadar teammütte suç tasavvuru, düşünme, vasıtanın seçilmesi, suç işleme için bir

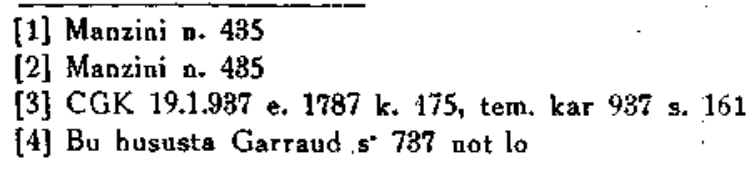


projenin hazırlanması gibi unsurlardan meydana gelmiş bir hâdise mevcut isede, bütün bu faaliyetin sükünet içinde cereyanı şart değildir. Bu sebeple tahrik edilmiş bir halde bulunan bir kimsede teammüt ile hareket edebilecektir. $\mathrm{O}$ halde teammüdün tahrik ile kat'î olarak gayri kabili telif olduğu söylenemez. Fakat eğer teammüt için soğukkanlılık şart olarak kabul edilirse o zaman hakikaten bu iki halin telifi imkânsız hale gelir [1].

Teammüt ile tahrikin bir arada bulunup bulunmayacağı meselesi hakkındaki kanaat, teammüdün sun'î bir müessese olup olmadız̆ kanaatı ile uygun olarak ele alınmalıdır.

Garafalo'nun bu mesele hakkındaki fikirlerinde büyük hakikat payı vardır : [2] \&Bazı katiller adam öldürmenin icra şekilleri ile birbirlerinden tefrik edilirler. Öldürürken tatbik ettikleri işkence, uzun azap çektirme onlarda doğuştan bir vahşetin mevcut olduğunu gösterir. Çünkü normal bir kimse mă̛durun yalvarması, ıstırap çekmesi, haykırmasını işiterek vucudunun titrediğini, acıdan kıvrandığını görerek fiile devam edemez. Feci ve sürekli işkence arzusu onlarda acıma duygusunun yoklư̧unu gösterir. Teammüt kıstası ile en fena katil sayılabilecekleri tefrik etmek imkânsızdır. Katil karakterinin kısa veya uzun süren bir suç işleme fikri ile alâkası yoktur. Bilâkis düşünmeğe zaman buldư̆u halde tipik suçlu olmayan insanlarda mevcuttur. Bu hale bilhassa failin aŏır bir hakarete maruz kalması, kendisinin ve ailesinin hayatını zehirleyen fahiş bir haksızlığa ư̆raması yahut intikamın kendisi için mukaddes bir vazife olduğuna inandı̆̆ı hallerde tesadüf edilir. Bazen suç, teammüden işlenmediợi hàlde, doğuştan bir vahşetin delili olabilir, bilhassa mağdur tarafından yaplmış bir tahrik hareketi yok ise, hak edilmemiş ve mutlak surette kabulü imkânsız bir taarruz katili normal insanlara yaklaştırır ve böyle bir taarruz ani, suçlarda oldư̆u gibi teammüden işlenmiş suçlarda da mevcut olabilir. $O$ kalde teammüt büyük canileri tefrik eden

[1] Poznolini (n. 141) şu mütalâayı serdetmekte ve teamüt ile tahriki kabili telif bulmaktadır. Teamüdün unsurları kanunda tarif edilmemiştir. Teamüdün esas unsuru ruhtaki soğukkanlilik diye kabul edilirse, gazap ve şiddetli elemle teamüdü telife imkân yoktur. Fakat evvelce söylediłimiz gibi tatbikatta haksız tahrikin väeudu kabul edilince *gazap veya siddetli elem* mevcut farzedilmekte ve bilfiil mevent olup olmadığı aranmaktadır. Mademki teamüt haksız tahrikin kabulüne hukakî bakımdan mâni deł̣jidir, o halde tahrik ve teamüt bì hâdisede birlikte kabul eóilebilir.

[2] Garafalo s. 406, 407 
derin psikolojik anormallið̌in delili sayılamaz, Hakikî katillerde bazen teammüt bulunmayabildiği gibi, hakikî katil olmayanlarda bazen teammüt bulunabilir. $O$ halde şu neticeye varlmalıdır. Fiilin vahşi bir şekilde işlenmesi ve mağdur tarafından ağır bir hakarette bulunulmamış olması, hakikî katillerden diğerlerini tefrik hususunda, teammüt yerine ikame edilmesi lâzım gelen kıstaslardir ".

Garafalo'nun bu fikirleri karşısında teammüt mefhumunun hakikatte gayri meveut ve sadece kanunda yazil ve binnetice hâdiselere sun'î olarak tatbik edilen bir unsur olduğu yolundaki kanaat kuvvetlenmektedir. Bu sebeple hakikatta mevcut olmayan bir unsurun tahrik ile kabili telif olup olmadığın araştırmakta bir faide umulamaz.

f. Tahrik ve meşru müdafaa : Tahrik ve meşru müdafaa aynı psikolojik hâdiselere dayanmakla beraber, kanunî hükümler bakımından aralarında esash farklar bulunan iki müessesedir. Psikolojik bakımdan meşru müdafaa azamî bir tahrik halidir. Bu sebeple tahrik, meşru müdafaada dahildir, ve mcşru müdafaa halinde tahrikten mütevellit hareket müdafaann unsurlaxın teşkil eder.

Meşru müdafaa cezayı kaldıran, tahrik sadece cezayı azaltan bir sebep olduğuna göre meşru müdafaanın kabul edildiŏi hallerde tahrik hükümlerinin tatbikine imkân yoktur, fakat meşrı müdafaa hududunun aşılması (aşın müdafaa) yani Ceza kanununun 50 inci maddesinde nizama konulan hâdise ile tahrik bir hâdisede birlikte bulunup bulunamayacăğ ihtilâf mevzuu olabilir ;

Meşru müdafaa halinde zaruretin tayin ettiği hududu aşanlara ceza verilir. fakat tecavüz bir tahrik mahiyetinde olduğundan verilen bu ceza tahrik sebebi ile azaltılır.

Fakat bu fikrin aksi de ileri sürülmüştür: Aşırı müdafaa, meşru müdafaa sebebinin de bulunmasını icap ettirir, ve aşırı müdafaa fiilinin saikleri meyanına 51 inci maddede yazlı fiilin saikleri de dahildir. Çünkü büyük küçüğü ihtiva eder. $O$ halde aşırı müdafaadan mütevellit cezayı azaltan sebep aynı suç ve aynı şahıs bakımından tahrik ile kabili telif değildir [1].

Bu iki fikir ceza kanunumuzun sistemine daha uygundur, çünkü kanunun 49 uncu maddesinde meşru müdafaayı bir ceza-

[1] Manzini n. 441 l; Bruno m. 51, İtalyan Ygt. kararı: ‘Aym suç için hem tahrik ve hem de meşru müdafaa hududunun aşılmaș kabul edilemez.» 
sızlık sebebi saydıktan sonra müdafaa heyecanı ile, korunmanın zaruri kıldı̆̆ı hududun așilması jhtimalini düşünerek, bu aşırı hale mahsus olmak üzere ayrı bir hüküm (madde 50) vazetmiştir. Bu sebeple kanunde hususî bir hükme mevzu teşkil eden bir hale aynı zamanda diğer bir hükmün de tatbiki yorum kaidelerine uymaz.

g. Tahrik ve kasdı aşan suçlar : Tahrik ile kasdı aşma halleri bir hâdisede birlikte bulunabilir. Kasdı aşma hali, gayenin aşılması şeklinde kendinigösterir ve fiilin maddî unsurunu ilgilendirir, bu sebeple meselâ ( katil kasdı ile olmayan bir müessir fuilden telifi nefs husule gelmesi) halinde 452 ve 51 inci maddelerin birlikte tatbiki mümkündür.

h) Tahrik ve tam olmayan akıl maluliyeti : Tam akıl maluliyeti ile tahrikin birleşmesi halinde cezasızlık sebepi olan akıl maluliyeti, tahriki beliğ eder. Tam olmayan akıl maluliyeti ise tahrik ile birleşebilir. Normal insanlar için kabul edilen tahrikin anormal olanlar için kabul edilmemesinde hiçbir sebep yoktur. Zaten bir kısım tam olmayan akıl maluliyetleri tahrike çok müsait bir durum meydana getirirler.

i) Tahrik ve iştirak : Tahrik mübjektif karekterli. cezayı azaltıcı bir sebeptir [1]. Bu bakımdan ne aslî ve nede fer'î faillere sirayet etmez [2]. Binaenaleyh ortaklardan baziları hakkında tahriki kabul etmek, bazıları hakkında da kabul etmemekte tenakuz yoktur [3]. Eğer feri fail taarruza maruz kalmıs ise eğer așli fail bundan tahrik edilmiş olursa yahut aksi cereyan ederse, her ikisi hakkında da tahfif sebebi tatbik olunur, fakat burada tahfif sebebi s sirayet stmiş değil, her ikisi hakkında da ayrı ayrı tesirler icra etmiştir.

Teşvik veya suç kararını takviye eden bir ortaơ̆ın bulunması asıl fail hakkında tahriki kabule mani deł̧ildir, çünkü asli fail eğer tahrik edilmeseydi, teşvik veya takviyeye mukavemet edebilirdi ve diø̌ger taraftan tahrik edilmiș olmasına rağmen eğer teşvik veya takviye görmeseydi, suçu işlemeyebilirdi [4].

j. Hususî tahrik halleri : Kanunumuzun sistemi, tahrik meselesini oldukça geniş bir surette ele almă̆a müsaittir. Kanunun

[1] Italyan Ygt. karari Bruno m. Бl

[2] bk. Oner s. 90

[3] Italyan Ygt. kararı Bruno m. 51; Manzini n. 442

[4] Manzidi n. 442 
umumì hükümleri meyanında ve binnetice bütün suçlara kabili tatbik bir tahrik hükmü (madde 51) yer almakta ve ceza kanununun hususî kısmında bazı suçlar hakkında ayrıca hükümler bulunmaktadrr. $O$ halde 10 uncu madde serahatına uyularak, hususi kısımda tahrike dair serahat bulunmayan suçlar için 51 inci maddenin ve serahat bulunan yerlerde de o maddelerin tatbiki icap eder. Fakat bir hâdiseye hem tahrik hakkındaki umumî hüküm ve hem de hususî kısımda yer alan hüküm tatbik edilemez [1]. Kanunumuzda hususî tahrik hükümleri şunladır :

aa. Zina halinde yakalama: Kanun zina halinde yakalanan kimse ile suç ortağı hakkında işlenecek müessir fiil ve adam öldürme suçları için muayyen kimseler lehine olmak üzere, cezayı azaltıcı bir sebep kabul etmiştir (madde 462). Bu hükmün esası, meselâ kocanın karısını zina halinde yakalaması neticesinde haksız bir tahrik karşısında kalacă̆ı, ve bununda koca üzerinde hiddet ve elem tevlit edecȩ̌̆i düşüncesidir.

Kanun bu hali iuris et de iure bir tahrik hali olarak kabul etmektedir. Bu hükmün kat'i bir manâyı ifade etmesi, ve madde şartları mevcut ise mutlâka tatbiki lâzım gelmesi, bazı hâdiselerde pekde muvafık olamaz. Eşinin zinası ile geçinen dejenere aile tiplerinde, günün birinde dǐ̆er bir sebepten dolayı işlenecek adam öldürme fiilinin failine bu maddeden istifade hakkın vermek dogru sayılmaz,

bb. Sövme ve hakarete sebebiyet verme: Kendisine hakaret edilen veya söğülen kimse, bu suçun .işlenmesine kendi haksız hareketiyle sebebiyet vermis ise failin cezasi indirilir (madde 485, f. 1). Eğer söğen veya hakaret eden şahıs, hakkında haksız yere şiddet kullanılması neticesinde sövmüßs veya hakaret etmis ise hareketi cezayı müstelzim değildir (madde 485, f. 1).

cc. Diğer hususî tahrik halleri : 461 inci maddenin son fikrası, 272 inci madde [2] hükümleride birer hususî tahrik hali sayılabilir.

[1] İtalyan Ygt. karar, Bruno m. 51. Tahrik, zina halinde yakalamadan mütevellit cezayı indirici sebep ile kabili telif degildir) (zina halinde yakalama daha agur ve ististisnai bir șiddette tahriktir.)

[2] CGK 11.2.935 e. 175 k. 69. kar 935: *Resmî sıfatı ahiz memurlar aleyhine işlenen taarruz ve hakaret suçlarında memur, memoriyet hududunu tecavüz ederek veya keyfi hareketlerle* bu suçların işlenmesine sebebiyet verdiğłi hallerde ceza kanunun 272 inci maddesinin tatbiki icap eder, 51 inci maddenin tatbiki yolsuzdur. 
K. Tahrikin çeşitleri: Kanun iki türlü tahrik kabul etmektedir: ăğır tahrik, hafif tahrik.

Bu taksim kanunî bir taksimdir, bu sebeple hâdisede tahrik kabul edilince hạgi çeşit tahrik kabul edildiŏinin de hükümde gösterilmesi lâzımdır.

Kanun, 51 inci maddenin birinci fıkrasında tahrikin şartlarını göstermiş ve ikinci fıkrasında ă̆ır tahrik halinde cezayı daha fazla indirileceğine dair büküm vazetmiştit, fakat bu ikinci fıkrada ağır tahrikten ne kastedildiği gösterilmemektedir [1].

Ağır tahrikin ne olduğunun kanunda gösterilmemiş olması, tahrikin ağır veya hafif olması hususunun takdiririnin hakime bırakılmasındandır [2]. Tahrikin ağırlığı takdir edilirken yalnız objẹtif araştırmala değil, aynı zamanda failin sübjektif ve ruhî durumunda yaplacak araştırmalara da baş vurulacaktır [3].

Tahrikin ağırlı̆ının takdiri davayı gören mahkemeye ait oldư̆u yolundaki içtihat takarrur etmiş saylabilirsede, hâdiselerin hususiyeti ekseriya yargitayın murakabesine sebebiyet vermektedir [4].

\section{§ 2. HAYRET}

Heyacanların çoğu bir haz veya elemle karışır, fakat haz veya elemden müstakil heyacanlarda vardır: Hayret gibi.

Hayret dikkati muayyen bir' şey veya hâdise üzerinde toplar ve bu şek ve hâdisenin hudutları dışında kalan unsurlar ihsas haline geçemezler.

Hayret heyecanındaki fizyolojik tınlama hareketsizliktir, fazla şiddette hayret "donup kalma * neticesini tevlit eder. "Istigrak" hali de bir nevi hayret sayllabilir.

Hayret içinde bulunan da genel bir ruhî duraklama mevcuttur. Duraklamaya karşı reaksiyon anî değildir, bu sebeple hayret az, çok uzayan bir ruh hâdisesidir.

[1] Florian n. 832

[2] CGK 21.9 .942 e. 92 k. 93: *Tahrikin hafif veya ăgur oldựunụn takdiri davayı gören mahkemeye aittir.*

[ ] İtalyan Ygt. kararı Bruco m. 51

[4] bk. CGK 18.5.931, tem. kar. 930-934 s. 138; CGK 5.2.943 e. 11 k. 10 
Büyük bir cür'et ile işlenmiş suçlarda, failin suçu, hiç bir mukavemet görmekeizin tamamlyyabilmesi, hayrete uğrayanların hareketsizliğinden istifade etmesi şeklinde izah edilebilir.

\section{§ 3. KORKU}

a. Fobi : Korku normal bir hâdisedir. Fakat korkunun marazî şekilleride mevcuttur, bunlara fobi denir. Fobilerin normal korkudan ayırt edilmesi «nisbet unsurus ile mümkün olur. Fobilerde korkuyu doğuran sebep ile şiddeti arasında büyük bir nisbetsizlik. görülür, bu nisbetsizlik bazen o kadar büyük olurki korkuya "sebepsiz korku" demek mümkün olur.

Fobi, ona tutulmuş olana musallattır. Şahıs kendini ondan kurtaramaz. Bu kimseler ekseriya korkularının mantıksızlığını idrak ettikleri halde mukavemet kuvvetini kẹndilerinde bulamazlar.

Bu korkular bazen muayyen bir şey üzerinde toplanır, buna "monophobie" derler, bir kumaş, bir mayi, korku sebebi olabilir, sokaktan, meydantan, yükseğe çıkmaktan, korkanlara tesadüf edilir, bu hal monofobi nin bir, nevi olan "mekân korkusuः dur.

Marazî korkuların şuur altına itilmiş unsurłarłara ilgili olduğu umumiyetle kabul edilmektedir. Kendisi hatırlamasa bile, küçükken, yüksek bir yerden düşme korkusu geçirmiş olanın boşluğa bakamaması, mesiekte yıpranmıs tiren makinistlerinin kazadan korktukları için trene binememeleri gibi hâdiseleri bu suretle izah etmek mümkündür. Idam sahnelerinde bulunmak zorunda kalmış olanların, bir gün kendilerinin de asılacağından marazî bir şekilde korkmaları da bu guruba dahildir.

b. Normal korku muhtelif fizyolojik tınlamalara müncer olan bir heyecandır. Başlıca fizyolojik değişmeler şunlardır : ani dermansızhk, olduğu yere mıhlanma, veya aşırı bir enerji ve hareket, söz söyleyememek, kadınlarda süt kesilmesi, ağız kuruması. ter dökme, tüy dikenlenmesi, sararma.

Büyük ve ani korkularda ölüm neticesi husule gelebilir.

Psikolojik deð̧işmeler, korkunun şiddetine bał̆lıdır. Korkunun en hafif şekli vesvese ile karışı çekingenlik ve en şiddetli şekli de "dehşet" halidir.

Hayret ile kork arasında bazı münasebeller mevcuttur. Bir 
çok heyecanlarda oldư̆u gibi korkuda da evvelâ bir hayret safhası ile başlar.

Korku ihsas alma, bunlari hifzetme, ve hatırlama melekeleri üzerine müessirdir. Korku şahısda aynı zamanda illüzyon ve halisünasyon lar da tevlit eder. Bir kimsenin kendisine taarruz eden şahsın elindeki zararsız bir şeyi, korku neticesinde, tehlikeli bir silâh zannetmesi, insanca hiç veya pek az zararla neticelenmiş bir tren kazasında bulunan şahsın yüzlerce kişiyi ölmüş olarak vagonların altında gördüğü yolunda şahadette bulunması bu suretle izah olunur.

c. Korku kaide olarak, cezaya müessir değildir. Fakat takdiri bir azaltıcı sebeb telâkki edilmesi mümkündür. «Dehşet \ hali Ceza Kanununun 48 inci maddesi hükmüne tabidir.

Askerî ceza kanunu (şahsi tehlike korkusu) na cezayı azaltıcı bir değer verilemiyeceğini tasrih etmektedir (As. Ck, m. 46).

\section{§ 4. YEIS}

Keder, passif veya aktif bir yeis haline sebeb olabilir. Passif yeiste, şahıs çökmüş bir haldedir, az düşünür, hareketsiz ve sessizdir, ancak yavaş sesle konuşur, hareketleri ender ve çok yavaştır. Şahıs dış alemden uzaklaşmış, ayrılmış gididir. "Alâka unsuru dikkatini kendi dışında cereyan eden hadiseler üzerinde toplamasına mani olur, ihsaslar hafizasında iz bırakmadan kaybolurlar.

Aktif yeisde şahıs hareket halindedir, konuşur, ağlar, haykırır, şikâyet eder, dış alemle ilgisini kesmemiştir, hassasiyette artış ve canlıık görülür, fakat "dikkat bozulmuş, sathi kalmış, nüfuz kabiliyeti silinmiştir, çünkü dikkatin teksifi için lüzumlu salâka unsuru" yok olmuştur.

Her iki yeis halindede dikkatin azalışı, bazan da kayboluşu, şahadet psikolojisi bakımından ehemmiyetlidir.

Yeis halinin skendi kendini itham veya başkasına "suç isnadı* ile neticelendiği de görülmüştür. Çünkü her iki yeis halinde de şuurda husule gelen bozulma illüzyon ve halisinasyon lar 
tevlit eder. Passif yeisde kendi kendin itham, aktif yeisde başkasına suç istinadına daha fazla tesadüf olunur [1].

\section{IKíNcl BöLüM}

\section{IHTIRASLAR}

Fikri sahada "sabit fikir" ne ise psikolojik sahada eihtiras" odur [2]. Ihtiras dıs alemin yalnız muayyen bir noktasını aydınlatan ve diğer sahalarını karanlıkta birakan, ruhi melekelerin muayyen bir istikametten ayrlmasina mani olan bir haldir.

İhtiras, şahıs ile dış alem arasındaki rabıtayı bozan bir unsurdur. Ihsaslar şahsa yanlı̧ veya diğer unsurlardan tecrit edilmiş olarak vasıl olur.

İhtiras şahsiyeti değiştirir, tanınmaz hale getirir.

Ihtirasta devamllık hakimdir. Heyecanda geçicilik, intirasta devamhllık, bunlan birbirinden ayırt etmege yarar. Ihtiras șiddetinin daima heyecan şiddetine üstün olduğu söylenemez. Tehevvüren katil ile "taammüden katil" suçlarında faillerin psikolojisinde görülen şiddet farkı buna misaldir. thtirasta müzminleşme hali görülür. Muvzuu ayn olan bir heyecan ile bir ihtirasın birlikte bulunması imkânsızdır, heyecan bulunan yerde ihtiras olamaz.

Ihtirasta bütün psikolojik hayatı kaplama hali gözükür. Bu yayılma ve hakim olma temayülü ihtirasın 'genişlik şiddeti»ni teşkil eder. Bu sebeble (alkolizm, hasislik, mevki hırsı, annelik aşki, memleket aşkı her zaman ihtiras deł̆ildir. Fakat ne zaman bir ferdin bütün enerjisi yalnız bu gayeye sarfedilirse o zaman ihtiras olurlar. Muhteris olan artık muhteris olduğu şey için yaşamağa başlar [3].

Umumiyetle ihtiras temayüllerden doğar, fakat ihtiras ile te-

[1] Altavilia s. 61: Birgün bir kadın yedi yaşındaki gocuğunu öldürdügünü haber verir, kendi kendini ihbar ederken büyük bir yeis içindedir ve kendinin gayritabii bir ana oldugunu söylemektedir. Tahkikat sonunda çocugun bir mur. darilik hastalığına müptela bulunduğu, annesi evde yokkłen àni olarak öldügü, ananın çocuga her zaman gayet büyük bir jhtimamla baktıgı ve çocuğun kendisi evde yokken ölmesinden kendini mesul tutap muazzep olduğu ve bunun neticesinde çocugunu öldürdügü yolunda kendisinde bir kanaat teşekkü! ettiğgi anlașilımıştır.

[2] Ribot'nun fikri bk. s. 5; aynı mahiyette Altavilla s. 63

[अ] Sarp s. 269 
mayül farklı ruh hadiseleridir, bu fark (mahiyet farkı olmayı, derece farkıdır) [1]. $O$ halde ihtiras üstün ve diğerlerini kendine çeken bir temayüldür.

Her şahısta her ihtiras mevcut olamaz. Ihtiras müsait bir ru* hi zemin bulmadıkça haricileşemez. Bu sebeble tekrar eden hadiseler bir ihtirastan ziyade itiyat tevlid edebilirler. Bu sebeble ihtiras ile doğuştan gelen ruhi ve bedeni kabiliyetler arasında rabıta mevcuttur. O halde ihtirasın doğuşu cistidad da ihtiyaç gösterir, lhtirasın teşekkülünde dơ̆uştan gelen unsurlara daha fazla yer veren müelliflere tesadüf olunur. Bir müelliflere göre, bu manaya gelmek üzere sinsan muhteris doğar s.

Ithtiras muhakemeye tesir eder, akli faaliyet ve intiras birlik. te bulunurlar, fakat ihtiras akla üstün gelir ve onu idare eder, istediği istikamete yürütür ve bundan mantıkı olmayan neticeler yani mantıksız hükümler ortaya çıkar. Bu sebeble keyif verici maddelere karşı olan ihtiras, meselâ bunların vücud iç̧in faideli oldư̛̆u yolunda bir netice çıkarmağa şahsı mecbur eder ve şa. hıs buna samimi olarak inanmał̧a başlar, çünkü normal muhakemedeki tenkit hassasını ihtiras susturmuştur. $O$ halde ihtirasta kendini makul ve meşru göstermek isteği vardır.

Ihtirasların teşekkülünde içtimai tesirler ihmal edilemez. Ihtiras istidadı ancak müsait muhitte netice verebileceğine göre, ih* tirasların saklı kalması mümkündür. (Bu sebeble her cemiyetin, her içtimai zümrenin ayrı ayrı ihtirasları vardır [2].

thtirasłarın nevileri pek çoktur. Bunlar umumivetle iki katagoride toplanabilir: Uzvi ihtiraslar, zihni ihtiraslar. Bu tasnif ih. tirasların kaynaklarına göre yapılan bir tasniftir. Çünkü bütün ihtiraslar psikolojik bir vakıadan başka bir şey değildir. Diğer taraftan ihtirasların uzvi ve zihni olarak ikiye taksiminde mutlak bir ayrillk aramak doğru değildir. Uzvi bir ihtirasın zihñi vasıflar arzetmesi mümkündür: sevgi ihtirası gibi. Temamiyle zihni gibi görülen ihtirasların da uzvi reaksyonlarla karıșması da mümkündür [3].

[1] Ongun s. 126; Sarp s. 269

[2] Ongan s. 127

[3] İhtirasların tasnifleri hakkında bk. Ongun s. 130, 131 


\section{§1. SEVGI IHTIRASI}

Sevgi ihtirası bir obsesyon halinde şahsa hakim olan bir ihtirastır. Obsesyon şuur sahasın daraltır ve bu hadise sevginin esas karakteri olan kinhisar* halini izah eder.

Sevgi ihtirasının patalojik bir hal olup olmadığı, psikoloklar arasında münakaşa edilmiştir. Bu münakaşanîn sevgi ihtirası içinde bulunan suçlular hakkında cak.l maluliyeti ' hükümlerinin tatbik edilip edilmiyeceği bakımından ehemmiyeti vardır. Umumiyetle sevgi ihtirasının patalojik bir hal olmadığı ve fakat hususi ve muayyen bir psikolojik durum ifade ettiơi fikri kabul edilmektedir. Bu sebeble nasıl "gebelik» bir hastalık değil, fakat muayyen ve hususi vastflara malik fizyolojik bir hal ise, sevgi ihtirası da bir hastalık değil, muayyen ve hususî vasıflara malik bir psikolojik haldir.

Sevgi ihtirası suç sahasına sinhisar hassasının doğurduğu «kıskançlık sebebiyle intikal eder. Kıskançlık şüphe doğurur, aşındırıcı kimyevì bir madde gibi şahsiyeti kemirir, büyük hir kısmını değiştirir. "Ihtiraslar da görülen yanlış muhakeme ve tenkit hassasının kayboluşu kıskançlıkta en vazıh misallerini bulur.

Kıskançiık içinde bulunan kimse hadiseleri yanlış de ğil, doğru olarak idrak eder. Fakat bunların tefsirinden çıkardığı neticeler yanlıştır' [1].

Kıskançlık iftira ve adam öldürme suçlarının saikleri arasında yer altr.

Kiskançlik adam öldürme vakalarında ekseriya alkol tesiri ile birlikte gözükür. Bu gibi hallerde kronik aikolizimi digerlerinden ayırmak lâzımdır. Çünkü kronik alkolizmdeki müzminleşmiş ruhi iktidarsızlık sevgi ihtirasının teşekkülüne müsait bir zemin hazırlayamaz. Kronik alkolizm de, digerlerine yer vermeyen mustakil bir ihtirastır. Sevgi yüzünden alkole alışanlar ve sevgisini unuttuğu halde alkol içme ihtirasından kendini kurtaramyanlar pek çoktur. Bu izahlara rağmen alkol ve sevgi ihtirasının birlikte tesir icra ettið̆i hadiselerin az olduơu iddia edilemez.

[1] Altavilla s. 65: Bir tren memuru, bir arkadası öidürmeģe teşebbüs etmiş ve sebebi sorulduğu zaman arkadaşını kendigine bir yoicu kadenla temas ettił̌nini anlatmış olduğunu ve kadının da karısı oldựunu "hissetmiş" bulundu. gunu bildirmiştir. 
Sevginin ceza mesuliyetine tesirini şu şekillerde tetkik etmek mümkündür :

a) Anormal suçlularda iki ayrı hale tesadüf edilir. Bazıları bașkalarının kendilerine așık olduğuna inanırlar, bunlara xerotoman , denir. Ekseriya mukabil cinsten bir kimsenin kendine aşı oldư̆una kanidir, fakat aynı cinsten bir șahıs hakkında da, bu kanaata sahip olanlara tesadüf edilmiştir, bu hale, rérotomanie homosexuelle denir.

Suçlunun kendine aşık olduğunu zannettiği kimseler ekseriya tanınmış kimselerdir, devlet adamlan, büyük müzisyenler, meş* hur avukatlar vesaire gibi. Bu suretle husule gelen yanlış düşüncenin menbå, tesadüfi bakış veya alelâde bir vak'adır, yanlış tefsir ile erotoman bu neticeye ulaşmıştır.

Bu nevi suçiular kendilerine aşık zannettikleri kimseleri izace başlarlar. Telefonla, mektup, çiçek göndermek gibi vasıtalarla hatta mesken masuniyetini ihlal suretiyle suç işlemeğe başlarlar. Kendileri yakalanınca, bütün başına gelenlerin, sevgilisine kavuşmasına mani olanlar işi oldư̆unu iddia ederler.

Erotoman olmayan anormal suçlulardaki kıskançlık hususi bir tetkike ihtiyaç göstermez. Akıl maluliyeti mefhumunun umumi tetkiki bunların psikolojisi hakkında kâfi bilgi vermektedir [1].

b) Normal suçlularda sevginin, cezaya müessir kanunî sebepler arasına sokulması imkânsızdır. Yalnız sevgi ihtirasının bir kimseyi intihara kadar götürebilecek müstesna bir şiddet arzeden bir ihtiras olması düşünülecek olursa bazı hallerde, bu tesiri nazara almamâk güçtür. Hâdiselerin hususiyetleri suçlunun şahsiyeti, kültürü, telâkkileri ve diğer unsurlar tetkik edilerek hüküm vermek yerinde oiur.

Bu sebeplerle sevgi ihtirasının takdiri azaltıcı bir sebep saylması dogrudur. Yargitay da bu fikirdedir : «Suçlunun iradesi üzerine müessir bir sevginin tevlit ettił̆i ihtiras saikası ile sevgisini reddeden kadını öldürmesi lehine cezayı azaltan bir hal ve sebep. olarak takdir edilmesi hukuk ve ceza prensiplerine aykırı değildirs [2].

[1] Eren, Akıl-malâliyeti, Adalet dergisi, 1946

[2] CGK 930 esas 20 karar 20; tem. kar. 938 s. 33 


\section{\$ 2. NEFRET VE INTIKAM IHTIRASI}

Nefret ihtirası, intikam isteğini doğurması itibariyle suç saikleri arasında yer alır. Intikam isteğinin hiddet heyecanından ileri geldiği ve aralarındaki farkın şiddet farkı olduğu iddia edilmiştir.

Hiddet de, şuur ve muhakemenin ortadan kalkması veya azalması, intikamda ise şuur ve muhakemenin mevcudiyeti bu iki hali birbirinden ayırır. Hiddet bir heyecan, intikam bir ihtirastır.

Hiddette gaye başkasına azap vermek değildir, halbuki intikamın yegâne gayesi budur.

Intikamda gayenin muayyen bir şahıs üzerinde toplanması şart değildir. Hedefsiz yani muayyen bir şahsa değil, bir topluluğa tevcih edilmiş intikamlara, bilhassa intikamın iptidaî şekillerinde tesadüf olunur. Ceza Hukukunun tarihçesinde yer alan ayrı kılanların mensupları arasındaki intikam şekli bu nev'e dahildir.

Intikam psikolojik sahada birbirine zıt iki unsurdan teşekkül eder, birincisi taarruza sevkeden, ikincisi düşünceye dayanan, hesaplayan, harekete geçiren unsurdur.

Ihtirasların bazıları sonsuz devam eder. bazıları da gayeye ulaşınca söner, intikam ihtirası bu sonunculardır.

Intikam ihtirası birçok suç şekillerine girebilir : Adam öldürme, müessir fiil, iftira, kasden yangın çıkartmak suçları ekseriya tesadüf olunan suçlardandır.

Intikam ihtirası anormal suçlarda da mevcuttur ve anormal suçlarda bu ihtiras en feci suçların işlenmesine sebep olur.

Intikam ihtirası sevki ile işlenen suçların bir şekli de "kan gütme»dir. Kan gütme adetine birçok memleketlerde tesadüf olunur. Gronlant sakinleri arasında bir adam öldürülmesi katilin, yahut çocuklarının veya yakın akrabalarından birinin öldürülmesini icabettirir, ełger akrabasından kimse yoksa, komşusu öldürülür [1]. Arap memleketlerinin bir kısmında suçlu yerine cezaya çarpılan kimseler yalnız erkek kardeşler, erkek çocuklardır. Cenup silavlarında kan davası evvelâ babanın. erkek pardeşin, reşit olan erkek evladın üzerinde tesirini gösterir. Kaliforniya civarındaki yerlilerin bazılarında bir katilden en iyi intikam almanın onun

[1] Westermarek C. 1 s. 35 
sevdiklerinden birini öldürmek olduğu yolunda bir kaide teessüs etmiştir, Arnavutlukta, Korsikada kan davalarına tesadüf olunur.

Memleketimizde de kan gütme mevcuttur. Nisbeten mahdut bir sahada görülmektedir. Bu işe alet edilenler ekseriya küçüklerdir. Memleketimizde kan gütme adeti ile mücadele hususî bir kanuna mevzu teşkil etmiştir. Bu kanunun tatbiki neticesinde kan gütme saiki ile işlenen suçların azaldığı görülmektedir. 